\title{
How Leadership Behaviors Affect Organizational Performance in Pakistan
}

\author{
Muhammad Akram, *Hassan Mobeen Alam, Liaqat Ali, Muhammad Muazzam Mughal \\ Faculty of Commerce, Hailey College of Commerce, University of the Punjab, Lahore-Pakistan \\ *hassanmobeen.hcc.pu.edu.pk@gmail.com
}

\begin{abstract}
The purposes of this study are to analyze which leadership behavior is most closely related with organizational performances based on both leader's and employee's perceived; and to what extent leadership behaviors have impact on organizational performances in public and private organizations. Two questionnaires were developed to capture leaders' behaviors and employees' responses. Sample comprises of five hundred managers and five hundred employees of different private and public sector organizations of Pakistan. Correlation analysis and regression analysis are used to analyze relationship and effects of leadership behaviors with and on organizational performances. Results indicate that: firstly, all leadership behaviors are positively interrelated with leader is perceived and employee has perceived organizational performances. Secondly, only monitoring leadership behavior has significant positive impact on leader's and employee's perceived organizational performance based on individual analysis; whereas, innovative role modeling, support for innovation, recognition and monitoring leadership behaviors have significant positive impact on leader's perceived and employee's perceived organizational performances based on pooled analysis.
\end{abstract}

Keywords: Leadership Behaviors, Organizational Performance, Pakistan.

\section{Introduction}

Leadership is vital and leaders have multiple responsibilities in organization because leadership is incorporated with different hierarchical levels like individuals, units and organizational levels (Dansereau et al., 1984; Yammarino et al., 2005). Evolution of research on leadership is not initial (Zaccaro \& Klimoski, 2001) but it has been done at leadership levels and different results have found from these different levels such as organizational level research provides area for business scholar; whereas, lower level managerial leadership research provides strong psychological vision. Role of leader in an organization is critically linked with performance of organization. Organizations can be more effective and flexible when significant investments are made by organization on employees and optimal fit level between information, work, technology, and people should be achieved by the organization because motivation, commitment and employees' abilities can be enhanced and performance of organization can also be positively affected by these types of practices (Huselid, 1995). Delany and Huselid (1996) also reported that organizational performance could also be improved through related HRM practices, extensive employees' training, employees' empowerment, and employees' participation. Furthermore, innovation in products and services also positively affected from all these practices (Guthrie et al., 2008). According to Huselid (1995) and Van-Loo and De-Grip (2003), productivity per employee, return on sales (ROS), and profit per employee can be used as proxies of organizational performance. On the other hand, perception scale introduced by Delaney and Huselid (1996) can be used as measure of performance of organization. Scale includes two important variables, which are: performance of firm according to the perceptions of their respondents about the same products of competitors and perception of respondents about the performance of firm similar to same organizations. Pearce and Conger (2002) reported that an organization or a group is enough to distribute or share the activity of leadership. This sharing stimulates informational leadership in organization (Fletcher and Kaufer, 2003) where empowerment is delegated to employees regarding taking decisions to accomplish their tasks (Conger \& Kanungo, 1988).

Van-de-Ven (1986) stated that organizations that compete in innovation, uncertain environments, and turbulent becomes critical engines for viability, prosperity, and growth because globalization has been increasing intense competition in product market activities and resource market activities. Through seedy development of new quality products, organization can easily attain advantageous positions in products market (Kessler \& Chakrabarti, 1996) (Clark \& Fujimoto, 1991) (Brown \& Eisenhardt, 1995), and organization can easily compete over intangible assets (Gardner, 2005). High performance of an organization can easily be achieved through adoption or adaption of a good leadership behavior in 
organization. Jong and Hartog (2007) reported that innovative role-modeling behavior of leadership is lined with putting efforts and championing in development, generating ideas, exploring opportunities, and innovative behavior. Providing vision leadership behavior is connected with providing directions for future actions, communication of preferred typos of innovation, and communication of explicit vision. Consulting leadership behavior is associated with incorporation of suggestions and ideas in decision, and examining before initiating changes. Delegating is linked with authority that is delegated to employees in better performing their jobs. Support for innovation leadership behavior is attached with acting friendly, helpful, patient, looking out, and listening innovative employee's interests. Recognition leadership behavior is linked with appreciation to innovative employees on their innovative performance, and monitoring leadership behavior is associated with checking-up on people, and ensuring effectiveness and efficiency. Resultantly, all leadership behaviors lead toward innovation and high organizational performance with and through the employees of organization. The purposes of this study are to analyze which leadership behavior is most closely related with organizational performances based on both leader's and employee's perceived; and to what extent leadership behaviors have impact on organizational performances in public and private organizations individually and collectively. Then, it will make easier to understand that which leadership behavior is more fruitful that could be suggested to adopt in public and private organization to achieve high organizational performance. For these purposes, remaining study is organized as: literature is reviewed in section 2; research methodology is explained in section 3; results are analyzed in section 4; and conclusions are described in section 5 of the study.

\section{Literature Review}

Recognition leadership behavior is linked with appreciation to innovative employees on their innovative performance, and, if, employee will not work accordingly then he will be punished. On the other side, providing vision leadership behavior is connected with providing directions for future actions, communication of preferred typos of innovation, and communication of explicit vision. Same as, in transactional leadership style, the role of supervisor, group performance and organizational performance is focused and it is based on system of punishments and rewards. In business, employees are rewarded when they are successful, and they are punished when they fail. Clear structures are created by transactional leader during work. Subordinates are always clear about what is required from them and what reward they will get but punishments are not mentioned always. Bass (1998) analyzed United States (US) managers and New Zealand managers that adopted transactional leadership. The basic purpose of this study was to clarify the difference between actual results and planned result, which are discussed at first levels of management. Whereas, Bass (1990) found when the managers implement transactional leadership in the organization then better performance and rewards are clearly defined at top-level management than lower level management. Lowe et al. (1996) conducted study while examining transformational leadership and transactional leadership at different level of the organization. Study analyzed that transformational leader-ship exists at lower level and transactional leader-ship exists at higher level. Support for innovation leadership behavior is attached with acting friendly, helpful, patient, looking out, and listening innovative employee's interests. In support for innovation leadership behavior employees are motivated and encouraged to do work and good relationships are established among leaders and employees. Same as, in transformational leadership style, a connection is formed between followers and leaders and followers are inspired and motivated by transformational leaders by seeing the importance of the task. Performance of group members is focused by these leaders, and they need the subordinates to fulfill their potential.

Boerner et al. (2007) conducted study to examine the impact of transformational leadership behavior on follower's innovation and performance. 91 German companies were targeted from which 91 leaders were taken as sample. Study was hypothesized in such a manner that follower's behavior enhances due to transformational leadership through stimulating the behavior of organizational citizenship; whereas, follower's innovation enhances through promoting controversial issues regarding their tasks. While examining, study empirically proved that all hypothesis are correct. Obiwuru et al. (2011) examined the effects of leadership styles on performance of small-scale organizations. Transactional and transformational styles of leadership were also considered. Outcomes and behaviors of transformational leadership were considered relevant for individual consideration, inspirational motivation and charisma, satisfaction, extra effort, and effectiveness respectively. Outcomes and behaviors of transactional leadership were linked with management by exception and contingent; and commitment and loyalty, productivity, and effort respectively. The models of OLS multiple regressions were estimated, specified 
and evaluated. The results showed that performance is highly positively affected by transactional styles of leadership, but insignificantly affected by transformational style of leadership. Transactional style of leadership is more appropriate as comparison with transformational style of leadership in inducing in small-scale industries and, therefore, for small-scale enterprises the transactional style of leadership is recommended. Wanga et al. (2011) examined the relationship between employee's, firm performance, and CEO leadership behavior in China from 125 firms. In this study, firstly, leadership categories of CEO behavior were inductively identified in context of China. 739 top managers of 125 firms were included for testing the hypothesis on the base of matched data. In order to examine the relationship, structural equation modeling (SEM) was used. Study concluded that relationship-focused leadership behavior of CEO is highly correlated with firm performance through the mediation of employee's attitudes. Li-Fei et al. (2010) conducted study to investigate the behavioral effects of leadership on the performance of University of Research through developing a research model. In this study, organizational performance includes teaching performance, research performance and satisfaction of teachers, and leadership behavior includes development and concerned leadership behavior, and three dimensions of structure. New faculty of Research University was sample of this study and self-perceived data was used to test the hypothesis of the study.

In order to find out the results, structural equation modeling (SEM) was used. Study found that organizational performance is positively affected by both development oriented leadership behavior and structure oriented leadership behavior in Research University. Elenkov (2002) conducted study and examined the impact of transactional leadership behavior and transformational behavior on performance of Russian companies. Support for innovation was constituted in model while examining the relationship between organizational performance and transformational leadership behavior, and how transformational leadership behavior is affected by group cohesiveness. Study found positive relationship between organizational performance and transformational leadership behavior, and organizational performance is positively correlated with transactional leadership behavior with the mediation of support for innovation. Providing vision leadership behavior is connected with providing directions for future actions, communication of preferred typos of innovation, and communication of explicit vision. Wang et al. (2010) examined the relationship between organizational performance and leadership styles. 246 questionnaires (valid) were reviewed, which were sent to the operators, executors and owners of corporations. Results found that organizational performance is significantly contributed by interaction of styles of leadership and positively correlated to vision providing and charismatic style of leadership. Innovative role-modeling behavior of leadership is lined with putting efforts and championing in development, generating ideas, exploring opportunities, and innovative behavior. Stoffers and Heijden (2009) portray a model to analyze the relationship between perceived and objective organizational performance, and innovative work behavior, in Small \& Medium size enterprises (SMEs) in Dutch. Organizational politics was constituted in model as moderating variable upon these relationships. Study predicted that organizational performance could be achieved through investing innovative work behavior.

\section{Methodology}

Population, Sample Size, and Instrument: Sampling is an integral to accomplish research objectives. Two questionnaires are developed where one for leaders/managers and one for employees. Questions related to leadership behaviors are included in questionnaire after reviewing Jong and Hartog (2007) and questions related to organizational performances are included in questionnaire after reviewing Ali et al. (2010). Five point Likert scale is applied in questionnaire coded as strongly disagree $=1$, disagree $=2$, neutral $=3$, agree $=4$, and strongly agree $=5$. Population consists of all public and private organizations that are operationalized in ninety-six cities of Pakistan. As regard to the sample, five hundred questionnaires were distributed in managers and five hundred questionnaires were distributed in employees of different private and public sector organizations operationalized in sixty-six cities (randomly selected) of Pakistan. In short, total one thousand questionnaires were distributed in managers and employees and nine-hundred and thirty-two questionnaires are received in response; however, response rate is $93.20 \%$. Non-probability sampling technique is used in which each respondent does not have equal chance to select as sample; therefore, these responses can be classified as sample size of this study. 
Reliability Analysis: Statistical Package for Social Sciences (SPSS) version 16 is used while analyzing the reliability of questions and this reliability is checked in terms of Cronbach's Alpha. This alpha should equal to one in experimental studies, and it should more from 0.60 in behavioral studies but in some cases it thinks good ranging from 0.50 to one. In this study, Cronbach's Alpha of questions related to leadership behaviors is 0.878 , alpha of questions related to employee is perceived organizational performance is 0.694 ; and alpha of questions related to leader is perceived organizational performance is 0.732 .

Variables and Hypothesis Modeling: This study is mainly consisted of two main variables, which are composed of sub-variables.

Table: 1 Main Variable and Sub-Variable

\begin{tabular}{ll}
\hline Leadership behaviors & Organizational Performance \\
\hline Innovative Role Modeling & \\
Providing Vision & Leader's Perceived Organizational Performance \\
Consulting & \\
Delegating & \\
Support for Innovation & Employee's Perceived Organizational Performance \\
Recognition & \\
Monitoring & \\
\hline
\end{tabular}

This study is hypothesized as:

H 1: Leadership Behaviors are positively correlated with Leader's perceived and Employee's perceived Organizational Performance.

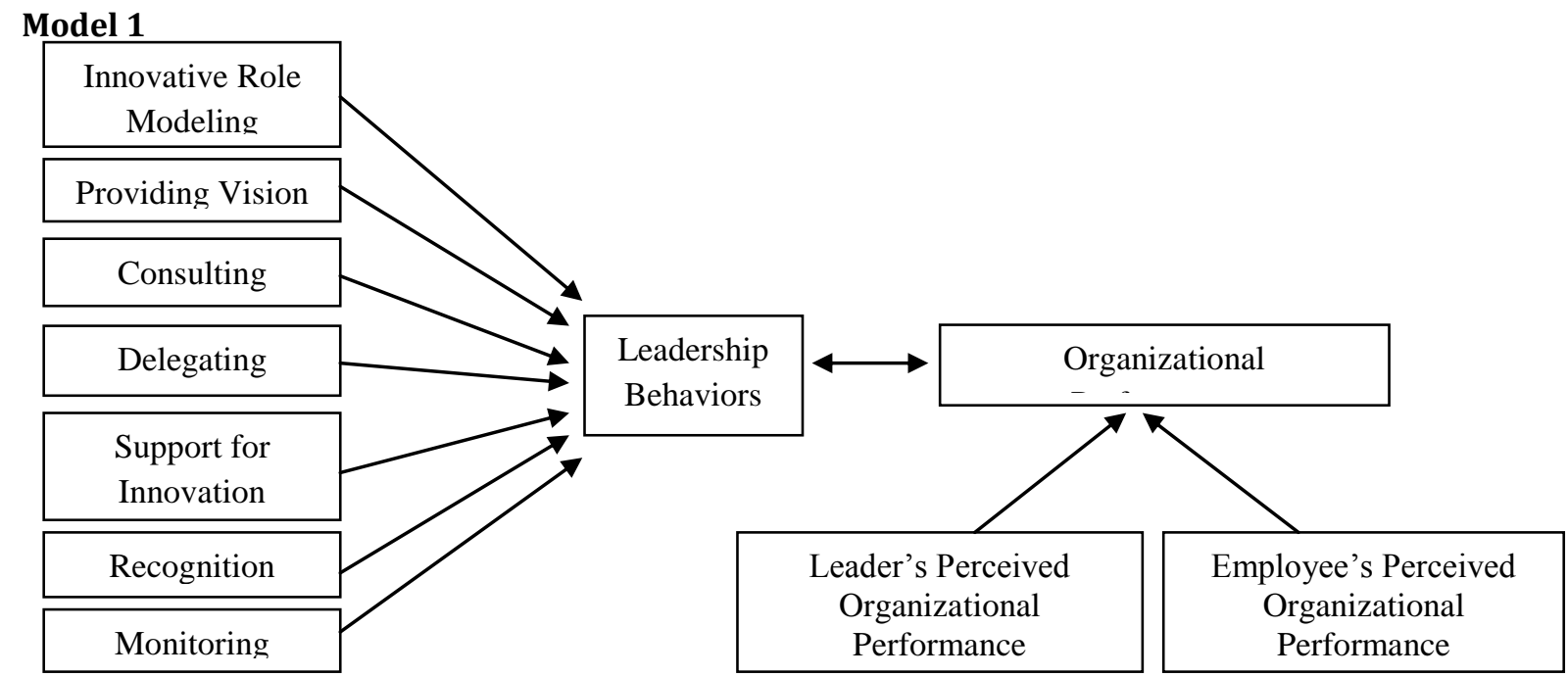

H 2: Leadership behaviors adopted in public organizations positively affect Organizational Performance. H 2a: Innovative Role Modeling Leadership behavior positively affects Organizational Performance.

H 2b: Vision Providing Leadership behavior positively affects Organizational Performance.

H 2c: Consulting Leadership behavior positively affects Organizational Performance.

H 2d: Delegating Leadership behavior positively affects Organizational Performance.

H 2e: Support for Innovation Leadership behavior positively affects Organizational Performance.

H 2f: Recognition Leadership behavior positively affects Organizational Performance.

H 2g: Monitoring Leadership behavior positively affects Organizational Performance.

H 3: Leadership behaviors adopted in private organizations positively affect Organizational Performance.

H 3a: Innovative Role Modeling Leadership behavior positively affects Organizational Performance.

H 3b: Vision Providing Leadership behavior positively affects Organizational Performance.

H 3c: Consulting Leadership behavior positively affects Organizational Performance.

H 3d: Delegating Leadership behavior positively affects Organizational Performance.

H 3e: Support for Innovation Leadership behavior positively affects Organizational Performance.

H 3f: Recognition Leadership behavior positively affects Organizational Performance.

H 3g: Monitoring Leadership behavior positively affects Organizational Performance. 


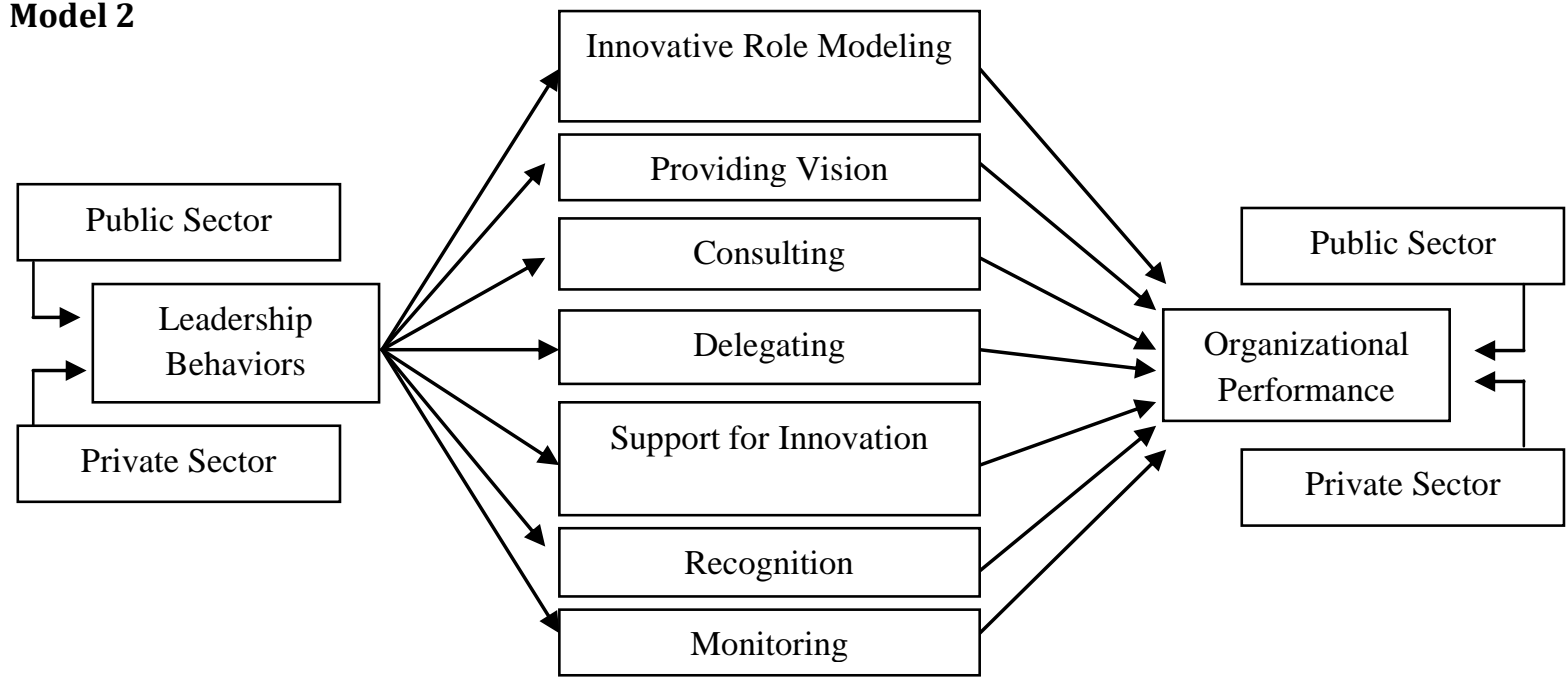

H 4: Leadership Behaviors positively affect Organizational Performance.

H 4a: Leadership behaviors positively affect leader's perceived Organizational Performance.

H 4a.1: Innovative Role Modeling Leadership behavior positively affects Leader's perceived Organizational Performance.

H 4a.2: Vision Providing Leadership behavior positively affects Leader's perceived Organizational Performance.

H 4a.3: Consulting Leadership behavior positively affects Leader's perceived Organizational Performance. H 4a.4: Delegating Leadership behavior positively affects Leader's perceived Organizational Performance.

H 4a.5: Support for Innovation Leadership behavior positively affects Leader's perceived Organizational Performance.

H 4a.6: Recognition Leadership behavior positively affects Leader's perceived Organizational Performance. H 4a.7: Monitoring Leadership behavior positively affects Leader's perceived Organizational Performance. H 4b: Leadership behaviors positively affect Employee's perceived Organizational Performance.

H 4b.1: Innovative Role Modeling Leadership behavior positively affects Employee's perceived Organizational Performance.

H 4b.2: Vision Providing Leadership behavior positively affects Employee's perceived Organizational Performance.

H 4b.3: Consulting Leadership behavior positively affects Employee's perceived Organizational Performance.

H 4b.4: Delegating Leadership behavior positively affects Employee's perceived Organizational Performance.

H 4b.5: Support for Innovation Leadership behavior positively affects Employee's perceived Organizational Performance.

H 4b.6: Recognition Leadership behavior positively affects Employee's perceived Organizational Performance.

H 4b.7: Monitoring Leadership behavior positively affects Employee's perceived Organizational Performance.

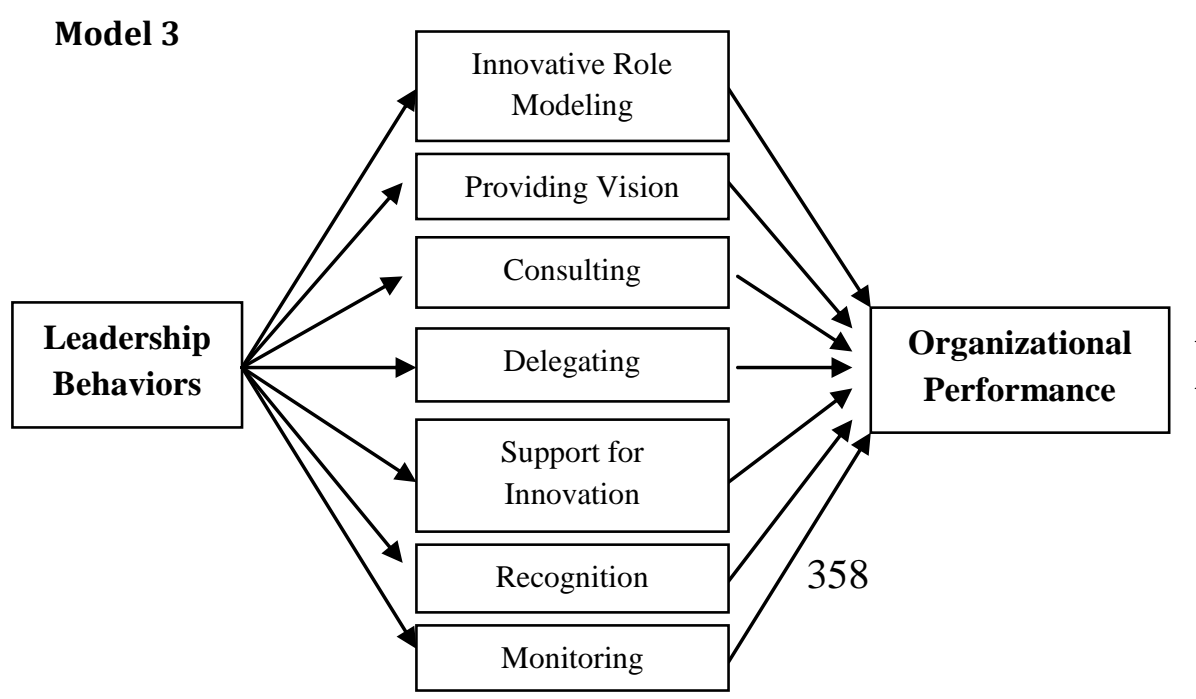

Employee's Perceived Organizational 
Analyses Tools: First, descriptive statistics is used to frame the demographic profile of respondents. Secondly, Elenkov (2002) applied correlation analysis to examine relationship between leadership and organizational performance; however, correlation analysis is used in this study to determine the relationship between leadership behaviors and organizational performances of both leader's and employee is perceived. Thirdly, Obiwuru et al. (2011) used regression analysis to analyze impact of leadership styles on organizational performance; however, regression analysis is used to investigate the impact of leadership behaviors on leader's perceived organizational performance and employee has perceived organizational performance. As regard to statistical software, Statistical Package for Social Sciences (SPSS) version 16 is used in determining descriptive results, correlation, and regression.

\section{Results}

Table 2: Respondent's Profile

\begin{tabular}{llll}
\hline Demographics & & N & Percentage (\%) \\
\hline \multirow{3}{*}{ Gender } & Male & 772 & 82.80 \\
& Female & 148 & 15.90 \\
Total & Missing & 12 & 01.30 \\
& & 932 & $100 \%$ \\
& Matriculation & 4 & 00.40 \\
\multirow{5}{*}{ Education } & Intermediate & 44 & 04.70 \\
& Bachelor & 300 & 32.20 \\
& Masters & 396 & 42.50 \\
& M. Phil. & 16 & 01.70 \\
Total & Ph.D. & 12 & 01.30 \\
& Professional Qualification & 144 & 15.50 \\
& Missing & 16 & 01.70 \\
Age & & 932 & $100 \%$ \\
& Less than 20 & 4 & 00.40 \\
& 20Years - 30 Years & 496 & 53.20 \\
Total & 31 Years - 40 Years & 200 & 21.50 \\
& 41 Years - 50 Years & 92 & 09.90 \\
Nature of Company & 51 Years - Above & 104 & 11.20 \\
& Missing & 36 & 03.90 \\
Total & Manufacturing & 932 & $100 \%$ \\
\hline
\end{tabular}

In this study, on the base of Table 2, total nine-hundred and thirty-two responses are received from respondents. There are: $772(82.80 \%)$ respondents are male; $148(15.90 \%)$ respondents are female; and remaining $12(1.30 \%)$ respondents did not report. Respondents are characterized into eight parts based on their education. There are: $4(00.40 \%)$ respondents have matriculation's certification; $44(04.70 \%)$ respondents have intermediate's certification; 300 (32.20\%) respondents have bachelor's certification; 396 (42.50\%) respondents have master's certification; 16 (01.70\%) respondents have M. Phil. Certification; $12(01.30 \%)$ respondents have Ph. D. certifications; $144(15.50 \%)$ respondents have attained professional qualification; and $16(01.70 \%)$ respondents did not report their qualification. Respondents are also characterized into six parts based of their age brackets. There are: $4(0.40 \%)$ respondents fall in age bracket of less than 20 years; 496 (53.20\%) respondents fall in age bracket of 20 Years - 30 Years; $200(21.50 \%)$ respondents fall in age bracket of 31 Years - 40 Years; 92 (9.90\%) respondents fall in age bracket of 41 Years to 50 Years; 104 (11.20\%) respondents fall in age bracket of above 50 Years; and 36 (3.90\%) respondents did not report their age. According to the nature of company, $208(22.30 \%)$ respondents have been working in manufacturing organizations, $560(60.10 \%)$ respondents have been working in service organizations, $136(14.60 \%)$ respondents have been working in trading organizations, and $28(3.00 \%)$ respondents did not report about nature of company.

\section{Correlation Analysis}

Following are the analysis 
Table 3: Correlation Analysis of Leadership Behaviors and Leader's and Employee's Perceived Organizational Performances

\begin{tabular}{|c|c|c|c|c|c|c|c|c|c|}
\hline & 1 & 2 & 3 & 4 & 5 & 6 & 7 & 9 & 10 \\
\hline 1 & 1 & & & & & & & & \\
\hline 2 & $0.581^{* *}$ & 1 & & & & & & & \\
\hline 3 & $0.412^{* *}$ & $0.464^{* *}$ & 1 & & & & & & \\
\hline 4 & $0.388^{* *}$ & $0.402^{* *}$ & $0.332^{* *}$ & 1 & & & & & \\
\hline 5 & $0.463^{* *}$ & $0.374^{* *}$ & $0.401^{* *}$ & $0.350^{* *}$ & 1 & & & & \\
\hline 6 & $0.515^{* *}$ & $0.524^{* *}$ & $0.388^{* *}$ & $0.410^{* *}$ & $0.595^{* *}$ & 1 & & & \\
\hline 7 & $0.512^{* *}$ & $0.454^{* *}$ & $0.426^{* *}$ & $0.291^{* *}$ & $0.388^{* *}$ & $0.390^{* *}$ & 1 & & \\
\hline 9 & $0.331^{* *}$ & $0.250^{* *}$ & $0.191^{* *}$ & $0.195^{* *}$ & $0.113^{* *}$ & $0.268^{* *}$ & $0.473^{* *}$ & 1 & \\
\hline 10 & $0.352^{* *}$ & $0.212^{* *}$ & $0.165^{* *}$ & $0.224^{* *}$ & $0.147^{* *}$ & $0.280 * *$ & $0.389 * *$ & $0.587 * *$ & 1 \\
\hline
\end{tabular}

**. Correlation is significant at 0.01 Level (2-tailed).

Note: 1=Innovative Role Modeling Leadership Behavior; 2=Vision Providing Leadership Behavior; $3=$ Consulting Leadership Behavior; 4=Delegating Leadership Behavior; 5=Support for Innovation Leadership Behavior; 6=Recognition Leadership Behavior; 7=Monitoring Leadership Behavior; 8=Leader's Perceived Organizational Performance; and 9=Employee's Perceived Organizational Performance.

In this study, correlation analysis is used to examine relationship between leadership behaviors and leader's and employee has perceived organizational performances. There are seven leadership behaviors that are examined in this study, which are named as: innovative role modeling leadership behavior, vision providing leadership behavior, consulting leadership behavior, delegating leadership behavior, support for innovation behavior, recognition leadership behavior, and monitoring leadership behavior. It is clearer from table 3 that all leadership behaviors are highly positively correlated with leader and employee has perceived organizational performances that support $\mathrm{H} 1$.

Here, regression analysis is used to examine the impact of different leadership behaviors on leader and employee has perceived organizational performances, which are adopted in public organizations. Table 4 is clearly showing the impact of leadership behaviors on leader is perceived and employee has perceived organizational performance. Leadership behaviors are independent variables and leader is perceived and employee has perceived organizational performances are dependent variables. In addition, standardized beta coefficients, $t$. value, and significance values are demonstrated to interpret the results, F-value, and $\mathrm{P}$-value is taken from ANOVA analysis table, and R Square and Adjusted R Square are demonstrated as model summary. According to Table 4, only monitoring leadership behaviors has significant positive impact on leader's perceived organizational performance that support $\mathrm{H} 2 \mathrm{~g}$, and leadership behaviors like innovating role modeling, vision providing, consulting, delegating, support for innovation, and recognition have no significant positive impact on leader's perceived organizational performance and employee's perceived organizational performance that do not support H 2a, H 2b, H 2c, H 2d, H 2e, and H $2 f$.

Table 4: Impact of Leadership Behaviors on Organizational Performance adopted in Public Sector Organization

\begin{tabular}{|c|c|c|c|c|c|c|c|}
\hline \multirow{3}{*}{$\begin{array}{l}\text { Independent } \\
\text { Dimension }\end{array}$} & \multirow[t]{3}{*}{ Dependent } & \multicolumn{6}{|c|}{$\begin{array}{l}\text { Organizational Performance } \\
\text { (Standardized Beta Coefficients) }\end{array}$} \\
\hline & & \multicolumn{3}{|c|}{ Leader's Perceived } & \multicolumn{3}{|c|}{ Employee's Perceived } \\
\hline & & Beta & t. & Sig. & Beta & t. & Sig. \\
\hline & Innovative & .139 & 1.173 & .244 & .228 & 1.808 & .074 \\
\hline & Modeling & & & & & & \\
\hline & Vision Providing & .036 & .302 & .763 & -.170 & -1.342 & .183 \\
\hline Leadership & Consulting & -.099 & -1.017 & .312 & -.034 & -.322 & .748 \\
\hline \multirow[t]{4}{*}{ Behaviors } & Delegating & -.024 & -.261 & .795 & .167 & 1.668 & .099 \\
\hline & Support for Innovation & -.198 & -1.847 & .068 & -.079 & -.689 & .492 \\
\hline & Recognition & .254 & 2.169 & .033 & .243 & 1.944 & .055 \\
\hline & Monitoring & .458 & 4.743 & $.000^{* *}$ & 0.308 & 2.706 & .008 \\
\hline & \multicolumn{3}{|l|}{7.621} & \multicolumn{3}{|l|}{5.060} \\
\hline P-Value & & \multicolumn{3}{|l|}{$0.000^{* *}$} & \multicolumn{3}{|l|}{$0.000^{* *}$} \\
\hline \multicolumn{2}{|l|}{ R Square } & \multirow{2}{*}{\multicolumn{3}{|c|}{0.317}} & \multicolumn{3}{|l|}{0.276} \\
\hline \multicolumn{2}{|c|}{ Adjusted R Square } & & & & \multicolumn{3}{|l|}{0.221} \\
\hline
\end{tabular}

**.P $<0.01$ 
Table 5: Impact of Leadership Behaviors on Organizational Performance adopted in Private Sector Organization

\begin{tabular}{|c|c|c|c|c|c|c|c|}
\hline \multirow{3}{*}{$\begin{array}{l}\text { Independen } \\
\text { Dimension }\end{array}$} & \multirow[t]{3}{*}{ Dependent } & \multicolumn{6}{|c|}{$\begin{array}{l}\text { Organizational Performance } \\
\text { (Standardized Beta Coefficients) }\end{array}$} \\
\hline & & \multicolumn{3}{|c|}{ Leader's Perceived } & \multicolumn{3}{|c|}{ Employee's Perceived } \\
\hline & & Beta & t. & Sig. & Beta & t. & Sig. \\
\hline & $\begin{array}{l}\text { Innovative } \\
\text { Modeling }\end{array}$ & .084 & .760 & .449 & .199 & 1.723 & .088 \\
\hline & Vision Providing & .024 & .205 & .838 & .015 & .126 & .900 \\
\hline Leadership & Consulting & .135 & 1.313 & .192 & -.004 & -.035 & .972 \\
\hline \multirow[t]{4}{*}{ Behaviors } & Delegating & .047 & .463 & .644 & .020 & .185 & .853 \\
\hline & Support for Innovation & -.222 & -1.999 & .048 & -.219 & -1.877 & .063 \\
\hline & Recognition & .031 & .277 & .782 & .089 & .752 & .453 \\
\hline & Monitoring & .414 & 3.523 & $.001^{* *}$ & .323 & 2.627 & .010 \\
\hline & \multicolumn{3}{|l|}{5.675} & \multicolumn{3}{|l|}{3.810} \\
\hline \multicolumn{2}{|l|}{ P-Value } & \multicolumn{3}{|l|}{$0.000^{* *}$} & \multicolumn{3}{|l|}{$0.001^{* *}$} \\
\hline \multicolumn{2}{|l|}{ R Square } & \multicolumn{3}{|l|}{0.262} & \multicolumn{3}{|l|}{0.192} \\
\hline \multicolumn{2}{|c|}{ Adjusted R Square } & \multicolumn{3}{|l|}{0.216} & \multicolumn{3}{|l|}{0.142} \\
\hline
\end{tabular}

Here, regression analysis is used to examine the impact of different leadership behaviors on leader and employee has perceived organizational performances, which are adopted in private organizations. Table 5 is clearly showing the impact of leadership behaviors on leader is perceived and employee has perceived organizational performance. Leadership behaviors are independent variables and leader is perceived and employee has perceived organizational performances are dependent variables. In addition, standardized beta coefficients, t. value, and significance values are demonstrated to interpret the results, F-value, and P-value is taken from ANOVA analysis table, and R Square and Adjusted R Square are demonstrated as model summary. According to Table 5, only monitoring leadership behaviors has significant positive impact on leader's perceived organizational performance that support $\mathrm{H} 3 \mathrm{~g}$, and leadership behaviors like innovating role modeling, vision providing, consulting, delegating, support for innovation, and recognition have no significant positive impact on leader's perceived organizational

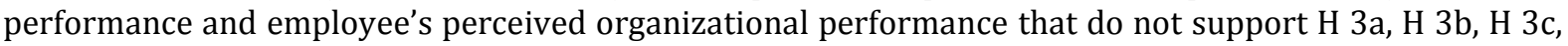
$\mathrm{H} 3 \mathrm{~d}, \mathrm{H} 3 \mathrm{e}$, and $\mathrm{H} 3 \mathrm{f}$.

Table 6: Effects of Leadership Behaviors on Organizational Performance

\begin{tabular}{|c|c|c|c|c|c|c|c|}
\hline \multirow{3}{*}{$\begin{array}{l}\text { Independent } \\
\text { Dimension }\end{array}$} & \multirow[t]{3}{*}{ Dependent } & \multicolumn{6}{|c|}{$\begin{array}{l}\text { Organizational Performance } \\
\text { (Standardized Beta Coefficients) }\end{array}$} \\
\hline & & \multicolumn{3}{|c|}{ Leader's Perceived } & \multicolumn{3}{|c|}{ Employee's Perceived } \\
\hline & & Beta & t. & Sig. & Beta & t. & Sig. \\
\hline & Innovative & 0.136 & 2.467 & 0.014 & 0.219 & 3.837 & $0.000^{* *}$ \\
\hline & Modeling & & & & & & \\
\hline & Vision Providing & -0.042 & -0.762 & 0.447 & -0.104 & -1.842 & 0.066 \\
\hline Leadership & Consulting & -0.028 & -0.577 & 0.565 & -0.044 & -0.886 & 0.376 \\
\hline \multirow[t]{4}{*}{ Behaviors } & Delegating & 0.046 & 1.002 & 0.317 & 0.088 & 1.851 & 0.065 \\
\hline & Support for Innovation & -0.206 & -3.930 & $0.000^{* *}$ & -0.150 & -2.763 & 0.006 \\
\hline & Recognition & 0.164 & 2.927 & $0.004^{*}$ & 0.172 & 2.975 & $0.003^{*}$ \\
\hline & Monitoring & 0.437 & 8.828 & $0.000^{* *}$ & 0.308 & 6.012 & $0.000^{* *}$ \\
\hline F-Value & & 23.669 & & & 17.755 & & \\
\hline P-Value & & $0.000^{* *}$ & & & $0.000^{* *}$ & & \\
\hline R Square & & 0.266 & & & 0.213 & & \\
\hline Adjusted R Sc & lare & 0.254 & & & 0.201 & & \\
\hline
\end{tabular}

**.P $<0.01, * . P<0.05$

Here, regression analysis is used to examine the impact of different leadership behaviors on leader and employee has perceived organizational performances. Table 6 is clearly showing the impact of leadership behaviors on leader is perceived and employee has perceived organizational performance. Leadership behaviors are independent variables and leader is perceived and employee has perceived organizational performances are dependent variables. In addition, standardized beta coefficients, $t$. value, and significance values are demonstrated to interpret the results, F-value, and P-value is taken from ANOVA 
analysis table, and R Square and Adjusted R Square are demonstrated as model summary. According to Table 6: support for innovation and monitoring leadership behaviors have high significant positive impact on leader's perceived organizational performance that support $\mathrm{H} 4 \mathrm{a} .5$ and $\mathrm{H}$ 4a.7; Recognition leadership behaviors has significant positive impact on leader's perceived organizational performance that support $\mathrm{H} 4 \mathrm{a}_{.6}$; and leadership behaviors like innovating role modeling, vision providing, consulting, and delegating have no significant positive impact on leader's perceived organizational performance that do not support $\mathrm{H} \mathrm{4a.1,}, \mathrm{H} \mathrm{4a.2,} \mathrm{H} \mathrm{4a.3}$, and $\mathrm{H} \mathrm{4a.4.} \mathrm{On} \mathrm{the} \mathrm{other} \mathrm{hand,} \mathrm{innovative} \mathrm{role} \mathrm{modeling} \mathrm{and}$ monitoring leadership behaviors have high significant positive impact on employee's perceived organizational performance that support $\mathrm{H}_{4} 4 \mathrm{~b}_{1}$ and $\mathrm{H}_{4} 4 \mathrm{~b}_{.7}$; Recognition leadership behaviors has significant positive impact on employee's perceived organizational performance that support $\mathrm{H}_{4} \mathrm{~b} .6$; and leadership behaviors like vision providing, consulting, delegating, support for innovation have no significant positive impact on employee's perceived organizational performance that do not support $\mathrm{H}$ 4b.2, H 4b.3, H 4b.4, and H 4b.5.

\section{Conclusion}

The purposes of this study are to analyze which leadership behavior is most closely related with organizational performances based on both leader's and employee's perceived; and to what extent leadership behaviors have impact on organizational performances in public and private organizations. Study indicated that:

- Firstly, with regard to relationship between leadership behaviors and organizational performances, leadership behaviors are positively correlated with leader and employee has perceived organizational performance (H1 accepted).

- Secondly, with regard to impact of leadership behaviors and organizational performances in public sector organizations, only monitoring leadership behaviors has significant positive impact on leader's perceived organizational performance ( $\mathrm{H} 2 \mathrm{~g}$ accepted), and leadership behaviors like innovating role modeling, vision providing, consulting, delegating, support for innovation, and recognition have no significant positive impact on leader's perceived organizational performance and employee's perceived organizational performance ( $\mathrm{H} \mathrm{2a}, \mathrm{H} \mathrm{2b}, \mathrm{H} \mathrm{2c}, \mathrm{H} 2 \mathrm{~d}, \mathrm{H} 2 \mathrm{e}$, and H $2 \mathrm{f}$ rejected).

- Thirdly, with regard to impact of leadership behaviors and organizational performances in private sector organizations, only monitoring leadership behaviors has high significant positive impact on leader's perceived organizational performance ( $\mathrm{H} \mathrm{3g}$ accepted), and leadership behaviors like innovating role modeling, vision providing, consulting, delegating, support for innovation, and recognition have no significant positive impact on leader's perceived organizational performance and employee's perceived organizational performance $(\mathrm{H} 3 \mathrm{a}, \mathrm{H} \mathrm{3b}, \mathrm{H}$ $3 c, \mathrm{H} 3 \mathrm{~d}, \mathrm{H} 3 \mathrm{e}$, and $\mathrm{H} 3 \mathrm{f}$ rejected).

- Lastly, with regard to impact of leadership behaviors and organizational performances on the base of pooled analysis, support for innovation and monitoring leadership behaviors have high significant positive impact on leader's perceived organizational performance $(\mathrm{H}$ 4a.5 and $\mathrm{H} 4 \mathrm{a} .7$ accepted); Recognition leadership behaviors has significant positive impact on leader's perceived organizational performance ( $\mathrm{H} 4 \mathrm{a}_{.6}$ accepted); and leadership behaviors like innovating role modeling, vision providing, consulting, and delegating have no significant positive impact on leader's perceived organizational performance ( $\mathrm{H} \mathrm{4a.1,} \mathrm{H} \mathrm{4a.2,} \mathrm{H}$ 4a.3, and $\mathrm{H} 4 \mathrm{a} .4$ rejected). On the other hand, innovative role modeling and monitoring leadership behaviors have high significant positive impact on employee's perceived organizational performance $\left(H 4 b_{.1}\right.$ and $H 4 b_{.7}$ accepted); Recognition leadership behaviors has significant positive impact on employee's perceived organizational performance ( $\mathrm{H}_{4} \mathrm{~b}_{6}{ }_{6}$ accepted); and leadership behaviors like vision providing, consulting, delegating, support for innovation have no significant positive impact on employee's perceived organizational performance ( $\mathrm{H} 4 \mathrm{~b}_{.2}, \mathrm{H} 4 \mathrm{~b}_{3}, \mathrm{H} 4 \mathrm{~b} .4$, and $\mathrm{H} 4 \mathrm{~b} .5$ rejected).

In this study, we have not examined different designs of leaderships. By using cross-sectional design, causal relationship cannot be substantiated in an initial exploration. Obviously, there is a need to adopt a longitudinal design; although, longitudinal design do not completely resolve substantiating causality difficulty and future research might benefit through incorporating leadership designs.

\section{References}

Ali, I., Rehman, K. U., Ali, S. I., Yousaf, J. \& Zia, M. (2010). Corporate social responsibility influences, employee commitment and organizational performance. African Journal of Business Management, 4(12), 2796-2801. 
Bass, B. M. (1990). From transactional to transformational leadership: Learning to share the vision. Organizational Dynamics, 3, 19-31.

Bass, B. M. (1998). Transformational Leadership, Laurence Erlbaum Associates, Hillsdale, NJ.

Boerner, S., Eisenbeiss, S. A. \& Griesser, D. (2007). Follower Behavior and Organizational Performance: The Impact of Transformational Leaders. Journal of Leadership \& Organizational Studies, 13(3), 15-26.

Brown, S. L. \& Eisenhardt, K. M. (1995). Product development: past research, present findings, and future direction. Academy of Management Review, 20, 343-78.

Clark, K. B. \& Fujimoto, T. (1991). Product Development Performance: Strategy, Organization, and Management in the World Auto Industry, Harvard Business School Press, Boston, MA.

Conger, J. A. \& Kanungo, R. N. (1988). The empowerment process: integrating theory and practice. Academy of Management Review, 13(3), 471-82.

Dansereau, F., Alutto, J. A. \& Yammarino, F. J. (1984). Theory testing in organizational behavior: The variant approach. Englewood Cliffs, NJ: Prentice-Hall.

Delaney, J. T. \& Huselid, M. A. (1996). The Impact of Human Resource Management Practices on Perceptions of Organizational Performance. Academy of Management Journal, 39(4), 949-969.

Elenkov, D. S. (2002). Effects of leadership on organizational performance in Russian companies. Journal of Business Research, 55(6), 467-480.

Fletcher, J. K. \& Kaufer, K. (2003). Shared leadership: paradox and possibility, Thousand Oaks, CA, 21-47.

Gardner, T. M. (2005). Inter-firm competition for human resources: evidence from the software industry. Academy of Management Journal, 48(2), 237-56.

Guthrie, J. P., Liu, W., Flood, P. C. \& MacCurtain, S. (2008). High performance work systems, workforce productivity, and innovation: A comparison of MNCs and indigenous firms. LINK Working Paper Series 04-08. Retrieved from: http:/link.dcu.ie/wp0408.pdf.

Jong, J. P. J. \& Hartog, D. N. D. (2007). How leaders influence employees' innovative behavior. European Journal of Innovation Management, 10 (1), 41-64.

Huselid, M. A. (1995). The impact of human resource management practices on turnover, productivity, and corporate financial performance. Academy of Management Journal, 38(3), 635-672.

Kessler, E. H. \& Chakrabarti, A. (1996). Innovation speed: a conceptual model of context, antecedents, and outcomes. Academy of Management Review, 21(4), 1143-91.

Li-Fei, X. B. \& Hua, J. (2010). Effects of Leadership Behavior on Organizational Performance in Research University. Management and Service Sciences, (MASS), 1-4.

Lowe, K. B., Kroeck, K. G. \& Sivasubramaniam, N. (1996). Effectiveness correlates of transformational and transactional leadership: a meta-analytic review of the MLQ literature. Leadership Quarterly, 7(3), 385-425.

Obiwuru, T. C., Okwu, A. T., Akpa, V. O. \& Nwankwere, I. A. (2011). Effects of Leadership Style on Organizational Performance: A Survey of Selected Small Scale Enterprises in Ikosi-Ketu Council Development Area of Lagos State, Nigeria. Australian Journal of Business and Management Research, 1(7), 100-111.

Pearce, C. L. \& Conger, J. A. (Eds.). (2002). Shared leadership: Reframing the how's and why's of leadership. Thousand Oaks, CA: Sage.

Stoffers, M. M. J. \& Heijden, V. D. B. (2009). Towards an HRM Model predicting Organizational Performance by Enhancing Innovative Work Behavior: A Study among Dutch SMEs in the Province of Limburg. Business Leadership Review, 6(4), 1-13.

Van-de-Ven, A. H. (1986). Central problems in the management of innovation. Management Science, 32 , 590-608.

Van-Loo, J. \& De-Grip, A. (2003). Loont het investeren in personeel? [Are investments made in employees profitable?] Maastricht: Researchcentrum voor Onderwijs en Arbeidsmarkt, Faculteit der Economische Wetenschappen en Bedrijfskunde, Universiteit Maastricht.

Wang, F. J., Chich-Jen, S. \& Mei-Ling, T. (2010). Effect of leadership style on organizational performance as viewed from human resource management strategy. African Journal of Business Management, 4(18), 3924-3936.

Wanga, H., Tsuib, A. S. \& Xind, K. R. (2011). CEO leadership behaviors, organizational performance, and employees' attitudes. The Leadership Quarterly, 22(1), 92-105.

Yammarino, F. J., Dionne, S. D., Chun, J. U. \& Dansereau, F. (2005). Leadership and levels of analysis: A state-of-the-science review. The Leadership Quarterly, 16, 879-919.

Zaccaro, S. J. \& Klimoski, R. (2001). The nature of organizational leadership: An introduction. San Francisco, CA: Jossey-Bass. 